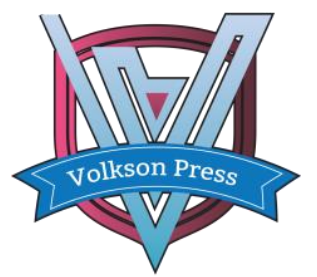

Contents List available at VOLKSON PRESS

Economics \& Management Innovations(EMI)

DOI : http://doi.org/10.26480/icemi.01.2017.238.241

\title{
Can Increase of the Rural Labor Force Price Promote Sustainable Utilization of Cultivated Land? -- Based on Panel Data Analysis of the County in Hubei Province
}

\author{
Xuye Liu 1 ,a \\ ${ }^{1}$ School of Management Wuhan Donghu University Wuhan City Hubei Province P.R.China. \\ aEmail:150119680@qq.com
}

This is an open access article distributed under the Creative Commons Attribution License, which permits unrestricted use, distribution, and reproduction in any medium, provided the original work is properly cited.

\section{ARTICLE DETAILS}

\section{Article History:}

Received 02 october 2017

Accepted 06 october 2017

Available online 11 october 2017

\section{Keywords:}

Labor price, Cultivated land, Sustainable utilization, Hubei province

\section{ABSTRACT}

Chinese agricultural is the small-scale peasant economy.The rising rural labor prices affects farmer production decisions which inevitably affect the cultivated land utilization. To take Hubei Province as a sample region, the BP neural network model was used to measure the level of sustainable utilization of cultivated land, and using the county-level panel data in 2003, 2008 and 2012 to establish the random effect model to investigate the influence of the rural labor force on the sustainable utilization of the cultivated land. The analysis results show that the influence coefficient of rural labor price on sustainable utilization of cultivated land is -0.1852 . The increase of labor price does not promote sustainable utilization of cultivated land, in contrast,does restrict. the fundamental reason is that the complete marketation of labor and capital and the nonmarketation of the land transfer results in unreasonable and unfull use of the resources.

\section{1. questions are put out}

In 2014 Chinese rural per capita net income is 8896 yuan that an increase of $11.2 \%$ over the previous year. In this year the labor income got growth of $16.5 \%$ much higher than family business income of $7.2 \%$. This means labor income for the first time in more than family business income in the rural per capita net income. Labor income become the main force to promote the growth of farmers' income, and the increase in the price of labor force play an important role in promoting the increase of labor income [1].Rural labor force can be divided into two categories according to whether to engage in agricultural production. One is the labor force completely out of agricultural production. The other is labor force engaged in agricultural production, which is divided into small farmers and big farmers. A small farmers is scale very little. And the small farmers not only engage in agricultural production, but olso engage in short-term workers that obtaining daily wage in the local. A big farmer have larger scale and needed to hire short-term labor force for agricultural production. Labor price increase will affect management decisions of the small farmers and big farmers for cultivated land. Decisions change of farmers will affect cultivated land utilization. Whether or not these changes caused by labor price increase will promote sustainable utilization of cultivated land? This paper try to answer this question. The current literatures studying the relation between labor force and land utilization are relatively few. And the study is in three aspects. One is the labor transfer effect on cultivated land utilization, for example Wang Yumeng [1] and Yang Zhihai [2]. The other is the impact of changing labour opportunity cost on land use (Chen Yuqi) [4]. Another is the influence of age and health of workforce on land use (Yang Jun) [5], (Yang Zhihai) ${ }^{[6]}$. It is very lack that labor price changed affects (positive or negative) on sustainable utilization of cultivated land. Therefore, the problem above will be discussed in this article.

\section{Measured Sustainable Utilization Level of Cultivated Land}

Hube is a big agricultural province where rice main production region. The agriculture population are more than 28 million. In 2014, per capita net income of farmers has just reached the national average, and per capita cultivated land resources are relatively scarce. So, farmers in Hubei province neither higher household income like eastern province, and lacking cultivated land like in western province. There are harder difficulties than the orther province in promoting sustainable utilization of cultivated land. Hence, it is more significant to choose Hubei province as the research area.

\subsection{The construction of evaluation index system}

According to sustainable land use evaluation content, which be put forward in land evaluation framework in 1993 by the world's food and agriculture organization (FAO), as well as the measure standard of land sustainable utilization. In this paper, we constructed the evaluation index system that including 31 indicators of cultivated land sustainable utilization in Hubei province from five aspects of the cultivated land productivity, stability, protective, economy and social. Following the objectivity, practical, data availability in the process of index selection, at the same time, draw lessons from the research achievements of predecessors, to measure sustainable utilization level of cultivated land in Hubei province.

\subsection{Build and train of the BP neural network evaluation model}

\subsubsection{Topology structure design of neural network model.}

The topological structure design of BP neural network model is very important. The three layers of network structure be chosen in this article. The neurons number of input layer is 31 , one neurons in output layer, neurons number of hidden layer $j$ can be determined according to the following formula,

$j=\sqrt{m+n}+\alpha$

In which, $m$ and $n$ is the neurons number of output layer, $\alpha$ ( $\alpha \in[1,10]$ ) is constant. Therefore, $j \in[7,16]$.

\subsubsection{The data source.}

In this paper BP neural network evaluation model data comes from statistical yearbook. The existing 106 counties in Hubei province. For some of countries that the urban land has very little or has not cultivated land, we merged them to form 82 counties. The data using for evaluation model is 2004, 2009 and 2014, most of them comes from Hubei rural statistical yearbook. A small number of data of land area and population etc. comes from the Hubei statistical yearbook. Missing data be filled a vacancy by the average of before and after years. The prices of 2004 as the base year that eliminating the effects of inflation. 


\subsubsection{Evaluation classification and training samples determining}

.The output of BP neural network model be in the interval $[0,1]$. Referencing the study of Tan Shu-kui [7], we divided the sustainable utilization level of cultivated land into six grades in Hubei province, such as excellent $[0.90,1]$, good $[0.75,0.90)$, common[0.60, 0.75$)$, bad $[0.45$, $0.60)$, worse $[0.30,0.45)$, very poor $[0,0.30)$.

According to Xu yue-qing [8] and Zhou xiao-fang [9], the data has been processed into six grades using linear interpolation. And selecting the average of the first two numbers and the two numbers in the middle respectively,the 372 data can be drawn and used as neural network input data. Six ranks of sustainable utilization level cultivated land and six median as output data, so we can get the network training samples. Sample data need to be normalized, normalized formula as follows.

$$
P_{i}=2\left(I_{i}-I_{\min }\right) /\left(I_{\max }-I_{\min }\right)-1
$$

In which, $P_{i}$ is the output value after normalized, $I_{i}$ is sample value, $I_{\min }$ is minimum sample value, $I_{\max }$ is maximum sample value.

\subsubsection{The BP neural network training.}

In this article, we took the BP neural network training through MATLAB2013a. To set the training parameters as follows, input layer is 31 , the output layer is 1 , neurons in hidden layer is 8 , the highest training times is 10000 , training step length is 0.001 , goal error is 0.0001 . The validation sample mean square error achieved the minimum 8.4163 e-5 after training, which less than the preset accuracy 0.0001 . Therefore, the network achieved the best performance. The trained network actual output values and the relative error are shown in table 1 . The average relative error between network actual output values and the desired output value is $1.72 \%$, so the network training effect is very good.

\section{Table 1 The Actual Output Values and Relative Error}

\begin{tabular}{|c|c|c|c|c|c|c|c|c|c|c|c|c|}
\hline $\begin{array}{l}\text { des } \\
\text { ire } \\
\text { d } \\
\text { out } \\
\text { put }\end{array}$ & 1 & 0.95 & 0.9 & $\begin{array}{l}0.8 \\
25\end{array}$ & $\begin{array}{l}0.7 \\
5\end{array}$ & $\begin{array}{l}0.6 \\
75\end{array}$ & 0.6 & $\begin{array}{l}0.5 \\
25\end{array}$ & $\begin{array}{l}0.4 \\
5\end{array}$ & $\begin{array}{l}0.3 \\
75\end{array}$ & 0.3 & $\begin{array}{l}0.2 \\
5\end{array}$ \\
\hline $\begin{array}{l}\text { act } \\
\text { ual }\end{array}$ & 0.9 & 0.9 & 0.89 & 0.8 & 0.7 & 0.6 & 0.6 & 0.5 & 0.4 & 0.3 & 0.2 & 0.2 \\
\hline $\begin{array}{l}\text { out } \\
\text { put }\end{array}$ & 91 & 60 & 7 & 28 & 60 & 83 & 07 & 40 & 50 & 74 & 95 & 27 \\
\hline $\begin{array}{l}\text { rel } \\
\text { ati } \\
\text { ve } \\
\text { err } \\
\text { or }\end{array}$ & $\begin{array}{l}- \\
0.9 \\
2 \\
\%\end{array}$ & $\begin{array}{l}1.0 \\
3 \\
\%\end{array}$ & $\begin{array}{l}- \\
0.38 \\
\%\end{array}$ & $\begin{array}{l}0.4 \\
1 \\
\%\end{array}$ & $\begin{array}{l}1.3 \\
8 \\
\%\end{array}$ & $\begin{array}{l}1.2 \\
3 \\
\%\end{array}$ & $\begin{array}{l}1.2 \\
5 \\
\%\end{array}$ & $\begin{array}{l}2.9 \\
2 \\
\%\end{array}$ & $\begin{array}{l}0.0 \\
9 \\
\%\end{array}$ & $\begin{array}{l}- \\
0.3 \\
0 \\
\%\end{array}$ & $\begin{array}{l}- \\
1.5 \\
4 \\
\%\end{array}$ & $\begin{array}{l}9.2 \\
3 \\
\%\end{array}$ \\
\hline
\end{tabular}

\subsection{The Evaluation Results}

Inputting 2004 data after the normalization processing into the trained network model, to obtain the sustainable utilization level of cultivated land of 82 counties in Hubei province. Similarly, inputting 2009 and 2014 processing data into the network model, to conclude the sustainable utilization level of cultivated land for 82 counties of Hubei province in 2004, 2009, 2014 years(omitting relative table).

\section{The Influence Mechanism of Labor Price on Sustainable Utilization of Cultivated Land}

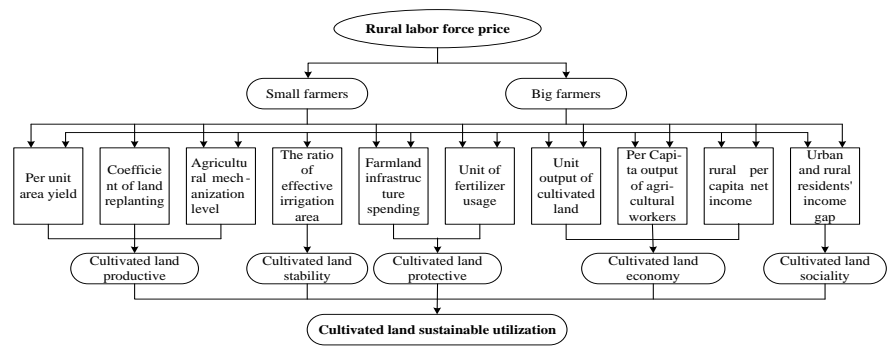

Figure 1 The Influence Mechanism of Rural Labor Price on Sustainable Utilization of Cultivated Land

Agricultural production needs to combine three production factors of cultivated land, labour and capital. When the labor price changed, the demand of the production unit for labor will change, which result in variety of the cultivated land and capital elements as shown in figure $1^{[10]}$.

\section{The Econometric Model and Analysis}

\subsection{Data Source of the Econometric Model}

The data of econometric model be obtained by the following way. The data that sustainable utilization level of cultivated land comes from BP neural network evaluation model. The rural labor force price is the average daily payment of male and female workers, which from statistics in agriculture bureau and price bureau. The data of urban construction land be from China city statistical yearbook and cities of Hubei province statistical yearbook. The data of 82 counties and its processing method is the same as the above 2.2.2.

\subsection{The Econometric Model}

Whether the increase in the price of labor to promote sustainable utilization of cultivated land, which can be determined through constructed econometric model. Combining the research of Zhu Li-fen and the influence mechanism of the rural labor force price on sustainable utilization of cultivated land[11], to establish econometric model as follows.

$L U S=C+\alpha A L P+\beta \sum_{i=1}^{5} C T R_{i}+\mu$

In formula (3), $L U S \in[0,1]$ is the sustainable utilization level of cultivated land, and to be explained variables. The data is based on the 82 counties of Hubei province in 2004, 2009, 2014. ALP as core explained variable, is the rural labor force price, which equal to the average daily payment of male and female workers. CTR is control variable that including five factors, such as per capita gross domestic product $G D P$, local government spending on agriculture, rural areas and farmers $G F E_{t-1}$, science and technology model household $S T H$, agricultural water supply from water conservancy facilities $A W S$, and agricultural tax policy $A P$ that is the virtual variables. Since abolished comprehensively agricultural tax in Hubei province, $A P$ is equal to 1 after 2005, and the other is 0 . The descriptive statistics of variables be shown in table 2 .

Table2 The Descriptive Statistics of Variables

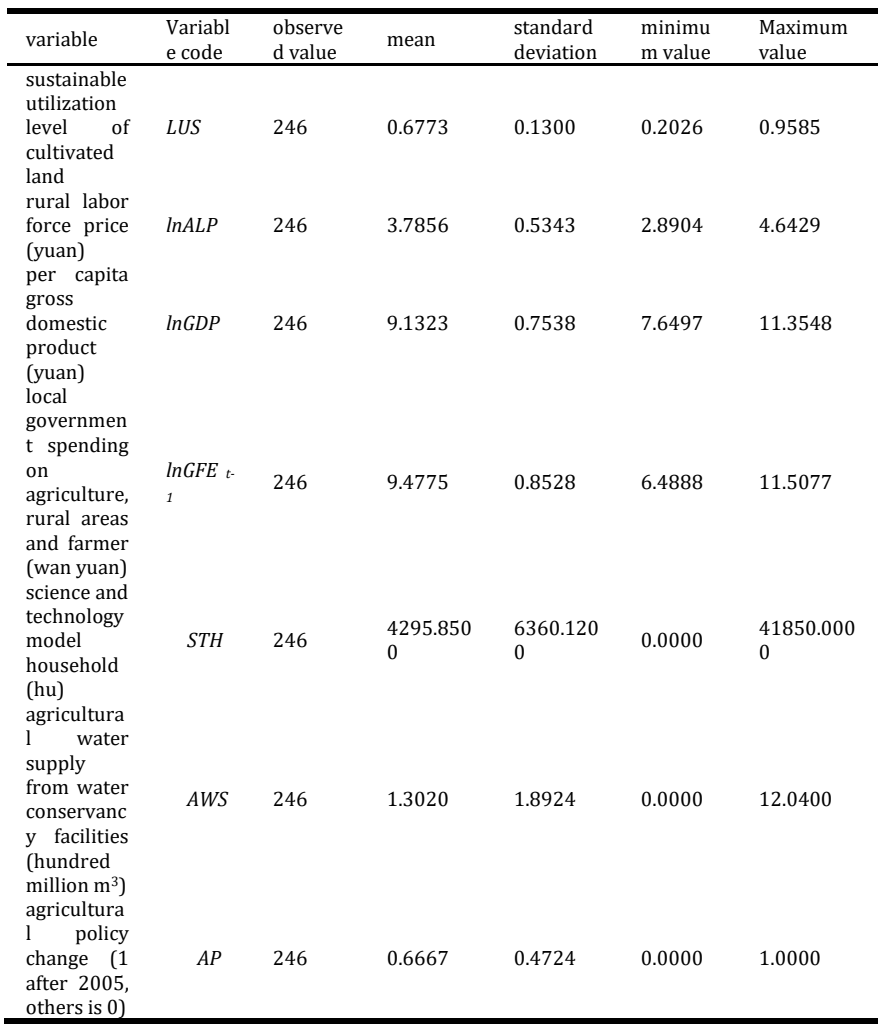

\subsection{The Model Estimation}

Combining with the feature of panel data, we chose three kinds of models that ordinary mixed model, the fixed effect model and random effect model. In this paper, the random effects model is better through test and comparison. The test results be shown in table 3 .

Table3 The Test Results of Model Chose

\begin{tabular}{lll}
\hline $\begin{array}{l}\text { Estimation } \\
\text { method }\end{array}$ & Test method & Test \\
& Results \\
\hline
\end{tabular}




\begin{tabular}{|c|c|c|c|c|}
\hline \multirow{2}{*}{$\begin{array}{l}\text { Mixed OLS, } \\
\text { Fixed effect }\end{array}$} & test: & $L R \chi^{2}(81)=309.52$ & & \multirow{2}{*}{$\begin{array}{l}\text { Fixed effect } \\
\text { model is } \\
\text { better }\end{array}$} \\
\hline & \multicolumn{3}{|c|}{ Prob $>\chi^{2}=0.0000$} & \\
\hline \multirow{2}{*}{$\begin{array}{l}\text { Mixed OLS, } \\
\text { Random } \\
\text { effect }\end{array}$} & \multirow[t]{2}{*}{ Breusch-Pagantest: } & $\chi_{0.05}^{2}(1)=72.36$ & ; & \multirow{2}{*}{$\begin{array}{l}\text { Random } \\
\text { effect } \\
\text { model is } \\
\text { better }\end{array}$} \\
\hline & & Prob $>\chi^{2}=0.0000$ & & \\
\hline \multirow{2}{*}{$\begin{array}{l}\text { Fixed effect, } \\
\text { Random } \\
\text { effect }\end{array}$} & Hausmantest: & $\chi^{2}(7)=8.50$ & & \multirow{2}{*}{$\begin{array}{l}\text { Random } \\
\text { effect } \\
\text { model is } \\
\text { better }\end{array}$} \\
\hline & \multicolumn{3}{|c|}{ Prob $>\chi^{2}=0.1305$} & \\
\hline
\end{tabular}

Table 4 The Results of Model Estimation

\begin{tabular}{|c|c|c|}
\hline variable & Random effect equation & $\begin{array}{l}\begin{array}{l}\text { Fixed } \\
\text { equation }\end{array} \\
\end{array}$ \\
\hline rural labor force price $(\ln A L P)$ & $-0.1852^{* * *}(0.0550)$ & $\begin{array}{l}-0.1609^{* * *}(0.0314 \\
)\end{array}$ \\
\hline per capita gross domestic product $(\operatorname{InGDP})$ & $\begin{array}{l}-0.0469^{* * *} \\
0.0144)\end{array}$ & $\begin{array}{l}-0.0494^{* * *}(0.0081 \\
)\end{array}$ \\
\hline $\begin{array}{l}\text { local government spending on } \\
\text { agriculture, rural areas and farmer } \\
\left(\ln G F E_{t-1}\right)\end{array}$ & $0.0022(0.0122)$ & $\begin{array}{l}0.0008 \\
0.0080)\end{array}$ \\
\hline $\begin{array}{l}\text { science and technology model household } \\
(S T H)\end{array}$ & $\begin{array}{c}0.0000 \\
0.0000)\end{array}$ & $0.0000(0.0000)$ \\
\hline $\begin{array}{l}\text { agricultural water supply from water } \\
\text { conservancy facilities }(A W S)\end{array}$ & $-0.0040(0.0039)$ & $\begin{array}{l}-0.0060^{\cdots *}(0.0018 \\
)\end{array}$ \\
\hline agricultural tax policy $(A P)$ & $0.1570^{* * *}(0.0462)$ & $\begin{array}{l}0.1426^{* * *} \\
)\end{array}$ \\
\hline $\begin{array}{l}\text { Sample capacity } \\
\qquad R^{2}\end{array}$ & $\begin{array}{l}246 \\
0.3624\end{array}$ & 246 \\
\hline Wald Test statistics & 170.88 & 374.82 \\
\hline
\end{tabular}

Note: ${ }^{* * *},{ }^{* *}$ and $*$ represent statistical significance level of $1 \%, 5 \%$ and $10 \%$ respectively. The values in brackets is standard error.

We estimated the parameters of the random effects model by Stata12.0 software. The estimation results are shown in table 4 . The partial effect of rural labor force to the sustainable utilization of cultivated land is -0.1852 . In order to test the robustness of the estimated results for random model, we adopted fixed effect model to eliminate section heteroscedasticity and serial correlation using two-stage generalized least squares (FGLS) in table 4. In which, the partial effect of rural labor force to the sustainable utilization of cultivated land is -0.1609 . Compared the results of the two model, the symbol has not changed of variables that core analytic and five control, coefficient variation is small. Therefore, the random effects model is stable (in table 4).

\subsection{Estimation Results Analysis}

According to the estimated results of the random effects equation, the partial effect of labor costs for the sustainable utilization of cultivated land is -0.1852 , and significance level is $1 \%$. This means labor actual price every increase $1 \%$ and sustainable utilization levels of cultivated land fell by $0.1852 \%$ in 2004 as a benchmark price, which shows labor costs significantly negative influence on sustainable utilization of cultivated land. There may be several reasons for this. Firstly, the current cultivated land management in Hubei province is given priority to with small farmers, less big farmers. When rural labor force price increases, small farmers engaged in day workers income more than the income of agricultural production. So, they will increase the rural manpower and decrease input of cultivated land and other various aspects, which lead to extensive management of cultivated land. Secondly, it means rising production costs rising for large farmers as rural labor force price higher, which will affect the output benefit of the cultivated land. Thirdly, the contradictions is obvious that between labor and capital of marketization and land (right) of the non-market, which not only affect reasonable configuration of cultivated land, but affect to make full use of labor force and capital in agricultural production. Eventually, to result in highly skilled workforce and rural capital outflow from the agricultural production. Sustainable utilization of cultivated land be impacted seriously.

The partial effect of per capita GDP, control variables, is -0.0469 , and statistically significant. Per capita GDP reflects the industrialization level of a national and regional reaction. Hubei per capita GDP is 7400 dollars in 2014. According to the experience of the developed countries, Hubei province is in the middle and late stage of industrialization. Cultivated land be occupied, high pollution and destruction in this stage. There is negative influence of per capita GDP on sustainable utilization of cultivated land. When the per capita GDP reached a certain level and into the later stage of industrialization, occupied and destructed cultivated land will greatly reduce. At that time, per capita GDP will positive impact on sustainable utilization of cultivated land [12]. The partial effect of local government spending on agriculture, rural areas and farmers is 0.0022 that very small but statistically insignificant. The partial effect of technology model household is 0 that not significant. The regression results almost no change when getting rid of this variable. The partial effect of agricultural water supply from water conservancy facilities is -0.0040 , which very small and not statistically significant enough. The partial effect of agricultural tax policy is 0.1570 , and statistically significant. Canceling the agricultural tax promote obviously sustainable utilization of cultivated land

\section{Conclusions and Implications}

Through the analysis of the econometric model above, the following conclusions can be draw. Firstly, the labor price increase will not promote, on the contrary, hinder sustainable utilization of cultivated land. Secondly, there are many reasons for the labor price increase obstacles to sustainable utilization of cultivated land. It need to pay more attention to labor and capital of marketization and land (right) of the non-market, which results in development uncoordinated in agricultural production factors of labor, capital and land market. Thirdly, the negative impact is the periodic that labor price increase for the sustainable utilization of cultivated land. As the rural population transferring to towns, cultivated land moderate scale operates step by step. The cultivated land factor market will coordinate for above three factors. From the above conclusion, it is concluded that the following enlightenment. The first, to attach importance to the role of labor costs in cultivated land sustainable. To optimize price mechanism of the labor, capital and land in the support policy of agricultural development. Especially, to change the current situation of rural high-quality labor loss using price mechanism, and to attract qualified workers from non-agricultural sector back into the agricultural sector. Second, it needs to reform the land system because lagging in land elements market. Accelerating the marketization of land circulation, to stimulate market vitality of cultivated land, and to better configuration and use of cultivated land resources. Third, it need to coordinated development in the elements market construction of labor capital and land in agricultural production.

\section{Acknowledgements}

This work was supported by the grants from Hubei Provincial Collaborative Innovation Centre of Agricultural E-Commerce ( under Construction ) (Wuhan Donghu university research [2015] No. 11 Document). Thone number:+86-013554521522

\section{References}

[1] Ding Shouhai. Supply Shortages and Rising Wages under the Condition of Surplus Labor - based on the Perspective of Family Division. Social Sciences in China, 2011, 05:4 21+219

[2] Wang Yumeng, Yang Zhihai. Labor Transfer, Capital Input and intensive Utilization of Cultivated Land. Journal of Jiangxi University of Finance \& Economics, 2013, 05:86 93 [3] Li Haitao, Yang Zhaoxian, Li Jinmeng. The Influence Rural Labor Transfer on Farmland Utilization in Different Economic Zone. Scientific and Technological Management of Land and Resources, 2011, 06: 22 28 [4] Chen Yuqi, Li xiubin, Zhu huiyi. The Impact of Opportunity Cost for Labour Farming on Farmers Decision of Arable Land Use- a Case of Hui County in Henan Province. Progress in Geography, 2010, 09:1067 1074

[3] Yang Jun, Yang Gangqiao, Hu Xianhui. The Impact of Agricultural Labor Age on the Farmers for Arable Land Use Efficiency--empirical from different level of economic development regions. Resources Science, 2011,09: 1691 1698

[4] Yang Zhihai, Li Peng, Wang Yapeng. The Impact of Rural Labor Force Aging on Farmers for Arable Land Use Efficiency. Areal Research and Development, 2015,05:167 171

[5] Tan Shukui, You Heyuan. The Evaluation on Sustainable Use of Urban Land in Hubei Province Based on BP Neural Network. Science \& Technology Progress and Policy, 2006,10:147 150

[6] Xu Yueqing, Li Shuancheng. Regional Differences Judgement of Economic Development Level in China with Artificial Neural Network. Resources Science, 2005,01:69 73

[7] Zhou Xiaofang, Zhou Yongzhang, Ouyang Jun. Residential Environment Evaluation for 3 Karst Rural in Guizhou Based on BP Neural Network. Journal of South China Normal University(Natural Science Edition), 2012, 03: 132 138

[8] Shao Changpeng, Du Jianjun. Rural Labor Transfer, Prices Dynamic Change and Convergence. Inquiry into Economic Issues, 2014, 
07:97 102

[9] Zhu Lifen, Huang Jikun. Research on the effects of urbanization on cultivated land. Economic Research Journal, 2007, 02:137 145
[10] Liu Yongjun. Empirical Study on Relationship between Agricultural Growth and Industrial Growth in Our Country. Chinese Rural Economy, 2005, 10:14 19 